Institution of Electrical Engineers' Wiring Regulations

THe booklet on "Regulations for the Electrical Equipment of Buildings" (price 1s. net) published by the Institution of Electrical Engineers has proved a great boon to the industry. It replaces many rules and regulations published by supply companies and insurance companies. The ninth edition was published in May 1927 and the tenth edition is in active prepara. tion. The new edition will contain rules relating to electric signs and to the new luminous discharge tube installations. These new rules have been approved by the representatives of those interested and by the Council of the Institution of Electrical Engineers. They deal very thoroughly with possible risks of fire and the precautions necessary to avoid risk of shock. These rules are now issued in advance of the tenth edition in a supplementary booklet. Copies of this supplement can be obtained free of charge, for insertion in existing copies of the Regulations, on application to the Secretary of the Institution of Electrical Engineers, Savoy Place, Victoria Embankment, London, W.C.2.

\section{Home-Grown Timber in Great Britain, 1930}

TнE Forestry Commission has issued a small pamphlet on home-grown timber (Report on Census of Production of Home-Grown Timber, 1930. H.M. Stationery Office. Dec. 30, 1932). The object of the pamphlet is to contrast the production or utilisation of timber in Great Britain in 1930 with the amount used in 1924. With this object, schedules were issued to woodland owners who had furnished returns in 1924. The census shows that there has been a falling-off between 1924 and 1930, both in respect of the volume and value of the material produced. As regards volume, there is a difference of 14 per cent, the decline being from $55,985,000$ cub. ft. in 1924 to $48,057,000$ cub. ft. in 1930 . The value of the material utilised has fallen in the same period from $£ 2,036,000$ to $£ 1,545,000$, representing a reduction of nearly 12 per cent. Prices ruled higher in England than in Scotland or Wales, but were certainly low as a whole, especially for the fine hardwoods such as oak (16d. per cub. foot in England with an average for Great Britain of 15d.; and $22 \frac{1}{2} d$. for ash in England with an average of $21 d$. for Great Britain-both for timber of saw-mill size). A little more than one-fourth of the total volume of material produced during 1930 consisted of the three fine hardwoods, oak, beech and ash (a total of 12,934,700 cub. ft.) and the figures demonstrate that the bulk of the fellings of these three valuable species were made in England, where 8,120,900 cub. $\mathrm{ft}$. (out of the 12,934,700 cub. ft.) were cut, of which $6,194,200$ cub. ft. were oak. Some of the fellings being made in these English woodlands are of the worst lumbering type-unchecked clear-felling and disposal of all that is saleable, the area being left clogged with rubbish and in a most unsightly state. It may be suggested that the time has arrived when a law prohibiting this type of unchecked lumbering, which has done such extensive harm to forest tracts throughout the globe, is urgently needed.

\section{Cultivated Oaks}

Srr Oscar Warburg and Mr. E. F. Warburg have published details of the oaks in cultivation in Sir Oscar's garden at Headley, Epsom, and elsewhere in the British Isles ("Oaks in Cultivation in the British Isles", J. Roy. Hort. Soc., 58, Pt. 1, pp. 176-189, Feb. 1933). The account is copiously illustrated with many clear photographs of herbarium specimens and the various species of the genera Lithocarpus and Quercus, which all come under the general category of 'oaks', are described in detail. Three sub-genera of Quercus are recognised-Cyclobalanopsis, Erythrobalanus and Lepidobalanus. A useful list at the end of the article sets forth the common name, the group and the area of origin in non-technical, as well as in botanical, language. Several notes on some South American oaks and garden forms help to clear up difficulties of classification, and a fairly extensive bibliography is added.

\section{A Polish Guide to Zoology}

The Polish Institute for the Promotion of Science and Letters is publishing a "Handbook for SelfEducation" (Poradnik dla Samoúkow) under the general editorship of Prof. S. Michalski, and vol. 10 (554 pages), dealing with histology, animal physiology, embryology and comparative animal psycho. logy, has just been issued (Warszawa. Imienia Mianowskiego. 18 złotys). This is the second section on zoology and contains contributions from Profs. Maziarski, Białisewicz and Godlewski, whilst Miss Bohn-Drzewina's article on animal psychology, originally written in 1929, is very fittingly appended. The object of this publication is to guide students (and lecturers) in their reading and to direct attention to general principles, to the historical developments and especially to the literature of each branch of the subject. It is not intended to supplant any of the standard textbooks but to supplement them. It is noticeable that the authors are most familiar with German treatises on the various branches of zoology under consideration, but some French and, more rarely, English works are cited and listed in the bibliographies. The work will prove useful to those Polish students who, for any reason, do not enjoy close contact with their lecturers, and it has apparently been compiled with that object in mind.

\section{Veterinary Research in the Union of South Africa}

The eighteenth report of the Director of Veterinary Services and Animal Industry, Onderstepoort, Pretoria, contains matter of value to the veterinarian and agriculturist. Several papers deal with parasitic and virus diseases of animals, and considerable space is devoted to the subjects of mineral deficiency and metabolism and to plants poisonous to stock. Mr. Bedford contributes an exhaustive synoptic check-list and host-list of ectoparasites found on South African mammals, birds, and reptiles, and Mr. Steyn has continued his observations on the effect of sulphur on merino sheep. A ration of $5 \mathrm{gm}$. of sulphur thrice weekly improves the condition of the sheep and 